\title{
Invasion of Dentinal Tubules by Oral Streptococci Is Associated with Collagen Recognition Mediated by the Antigen I/II Family of Polypeptides
}

\author{
R. M. LOVE, ${ }^{1,3}$ M. D. MCMILLAN, ${ }^{2}$ AND H. F. JENKINSON ${ }^{3 *}$ \\ Departments of Oral Rehabilitation ${ }^{1}$ and Stomatology ${ }^{2}$ and Molecular Oral Biology Laboratory, ${ }^{3}$ \\ School of Dentistry, University of Otago, Dunedin, New Zealand
}

Received 2 June 1997/Returned for modification 15 August 1997/Accepted 23 September 1997

\begin{abstract}
Cell surface proteins SspA and SspB in Streptococcus gordonii and SpaP in Streptococcus mutans are members of the antigen I/II family of polypeptides produced by oral streptococci. These proteins are adhesins and mediate species-specific binding of cells to a variety of host and bacterial receptors. Here we show that antigen I/II polypeptides are involved in the attachment of oral streptococci to collagen and that they also determine the ability of these bacteria to invade human root dentinal tubules. Wild-type $S$. gordonii DL1 (Challis) cells showed heavy invasion of tubules to a depth of approximately $200 \mu \mathrm{m}$, whereas the abilities of cells of isogenic mutant strains OB220 $(s s p A)$ and $\mathrm{OB} 219(\operatorname{ssp} A s s p B)$ to invade were 50 and $>90 \%$ reduced, respectively. Likewise, wild-type $S$. mutans NG8 cells invaded dentinal tubules, whereas cells of isogenic mutant strain 834 (spaP) did not. The invasive abilities of strains OB220 and OB219 were restored by heterologous expression of $S$. mutans SpaP polypeptide in these strains. The extents of tubule invasion by various wild-type and mutant strains correlated with their levels of adhesion to type I collagen, a major component of dentin. Furthermore, $S$. gordonii DL1 cells exhibited a growth response to collagen by forming long chains. This was not shown by ssp mutants but was restored by the expression of SpaP in these cells. The production of SspA polypeptide by $S$. gordonii DL1, but not production of SspB polypeptide by strain OB220 (sspA), was enhanced in the presence of collagen. These results are the first to demonstrate that antigen I/II family polypeptides bind collagen and mediate a morphological growth response of streptococci to collagen. These antigen I/II polypeptide activities are critical for intratubular growth of streptococci and thus for establishment of endodontic infections.
\end{abstract}

Oral streptococci are the most frequently implicated etiological agents in dental coronal surface caries (48) and are strongly associated with the development of root surface caries $(3,4)$; when they are introduced into the circulation, they may contribute to the development of cardiac vegetations in bacterial endocarditis (18). Each of these disease processes involves specific streptococcus-host interactions, with the primary event being the adhesion of streptococcal cells at the infection site. Although a number of streptococcus cell surface molecules that are involved in adhesion and colonization have been well characterized (22), the molecular bases of the infection processes are far from being fully understood.

Most indigenous species of oral streptococci produce cell wall-anchored polypeptides of the antigen I/II family. These proteins contain between 1,500 and 1,566 amino acid (aa) residues and have species-specific binding properties (21). Discrete regions within SpaP produced by Streptococcus mutans and $\mathrm{SspB}$ in Streptococcus gordonii have previously been shown to bind salivary proteins and glycoproteins and other oral microorganisms, such as Actinomyces naeslundii and Porphyromonas gingivalis (21). Evidence suggests that SpaP (also designated PAc or Sr) in $S$. mutans is essential for adhesion of this bacterium to salivary pellicles $(24,25,28,38)$, and although the SspA and SspB polypeptides produced by $S$. gordonii are not essential for the binding of cells to an experimental salivary pellicle $(9,23)$, they are nevertheless multiligand adhesins (9).

* Corresponding author. Present address: Department of Oral and Dental Science, University of Bristol, Dental Hospital and School, Lower Maudlin St., Bristol BS1 2LY, United Kingdom. Phone: 44117 928 4304. Fax: 441179284428.
Oral streptococci also express surface proteins that bind to extracellular matrix components, such as fibronectin and collagen. The ability of bacterial cells to bind to fibronectin may be a factor in the development of infective endocarditis (2), and CshA adhesin (259 kDa), which is produced by $S$. gordonii, Streptococcus sanguis, and Streptococcus oralis (36), mediates the binding of $S$. gordonii cells to immobilized fibronectin (37). The adhesion of oral streptococcal cells to collagen may be important in the development of root surface caries since collagen is a major component of dentin (29). Mutans group streptococci have previously been shown to recognize and adhere to collagen immobilized on hydroxylapatite surfaces (30) and within dentin (47), and the adhesion of $S$. mutans UA140 to collagen has previously been associated with the expression of a $90-\mathrm{kDa}$ polypeptide (27).

Bacteria and their products are central to the development of pulp and periapical diseases (46), and bacteria within root dentinal tubules can be associated with persistent root canal infection (15). Bacteria may enter the root canal system directly via carious lesions or pulp exposure after trauma (42). However, most infections of the pulp occur as a result of bacterial penetration of exposed dentin and enamel-dentin cracks and around restorations $(33,40)$ and then invasion of dentinal tubules. Although root canal infections harbor a complex but selective microflora (46), infection through dentinal tubules occurs predominantly by gram-positive bacteria, mainly streptococci (42). These bacteria are not motile, so invasion is relatively slow, and many previous in vitro studies have shown that bacteria penetrate into tubules over several days and then remain viable for prolonged periods $(1,15)$. The presence of a dentinal smear layer impedes bacterial penetration (32), whereas the depth of invasion may depend upon at 
TABLE 1. Bacterial strains and plasmids used in this study

\begin{tabular}{|c|c|c|}
\hline $\begin{array}{l}\text { Bacterial strain } \\
\text { or plasmid }\end{array}$ & Genotype and/or phenotype & $\begin{array}{l}\text { Source or } \\
\text { reference }\end{array}$ \\
\hline \multicolumn{3}{|l|}{ Strains } \\
\hline \multicolumn{3}{|l|}{ S. gordonii } \\
\hline DL1 (Challis) & Wild type & 39 \\
\hline OB220 & ssp $A::$ erm $A M$ & 23 \\
\hline OB219 & $\operatorname{ssp} A^{\prime} \operatorname{ssp} B^{\prime}:: \operatorname{erm} A M$ & 9 \\
\hline OB573 & ssp $A::$ erm $A M \mathrm{Kn}^{\mathrm{r}}(\mathrm{pSMI} / \mathrm{II}-3)$ & This study \\
\hline OB576 & $\operatorname{ssp} A^{\prime} \operatorname{ssp} B^{\prime}:: \operatorname{erm} A M \mathrm{Kn}^{\mathrm{r}}(\mathrm{pSMI} / \mathrm{II}-3)$ & This study \\
\hline OB277 & $\operatorname{csh} A 31::$ cat cshB2::ermAM & 37 \\
\hline \multicolumn{3}{|l|}{ S. mutans } \\
\hline NG8 & Wild type (serotype c) & K. W. Knox \\
\hline 834 & spaP::tet & 28 \\
\hline \multicolumn{3}{|l|}{ Plasmids } \\
\hline pSMI/II-3 & $\begin{array}{l}14.0 \mathrm{~kb} ; \mathrm{Kn}^{\mathrm{r}} \text { spaP rep (pVA380-1) } \\
\quad \text { ori }(\mathrm{ColE} 1)\end{array}$ & 19 \\
\hline pAM401-EB5 & $15.7 \mathrm{~kb} ; \mathrm{Cm}^{\mathrm{r}} \operatorname{ssp} B$ rep cop & 8 \\
\hline
\end{tabular}

least in part tubule diameter since this determines the rate of solute diffusion (34).

Although members of the sanguis group streptococci, e.g., $S$. gordonii, are among the bacteria that most efficiently invade dentinal tubules in experimental infections, the molecular attributes of these organisms which enable them to invade is not known. Accordingly, we investigated the role of specific cell surface polypeptides of $S$. gordonii in dentinal tubule invasion by determining the invasive properties of isogenic mutants. Here we show that cell surface antigen I/II family polypeptides SspA and SspB confer on $S$. gordonii cells the ability to invade dentinal tubules. We also provide evidence that invasion may be associated with a physiological growth response of cells to binding collagen that is present in an unmineralized form within dentinal tubules (7).

\section{MATERIALS AND METHODS}

Bacterial strains, plasmids, and culture medium. The strains and plasmids used in this study are listed in Table 1. Bacteria were cultivated in brain heart infusion medium (Difco Laboratories, Detroit, Mich.) containing 0.5\% (wt/vol) yeast extract (BHY medium). Kanamycin $(250 \mu \mathrm{g} / \mathrm{ml})$ was included where appropriate to ensure the maintenance of plasmids. Cultures were inoculated from stock suspensions stored at $-80^{\circ} \mathrm{C}$ in $\mathrm{BHY}$ medium containing $15 \%$ (vol/vol) glycerol and were grown at $37^{\circ} \mathrm{C}$ in closed tubes or bottles without shaking. Bacterial cells were radioactively labeled by growth in BHY medium containing [methyl $-{ }^{3} \mathrm{H}$ ]thymidine $(6 \mu \mathrm{Ci} / \mathrm{ml}$ [85 Ci/mmol]; Amersham Corp., Arlington Heights, Ill.) (23) to a specific radioactivity of between $7 \times 10^{-4}$ and $2 \times 10^{-3}$ cpm per cell. S. gordonii cells were transformed as previously described (16), and transformants containing plasmid DNA were selected on TSBY agar (23) containing $5 \mu \mathrm{g}$ of chloramphenicol per $\mathrm{ml}$ or $250 \mu \mathrm{g}$ of kanamycin per $\mathrm{ml}$ as appropriate.

Invasion of dentinal tubules. Noncarious, unrestored human teeth with single root canals were prepared for invasion experiments as described in detail elsewhere (34). Briefly, 200 root specimens were prepared from 100 teeth collected from numerous subjects. The two root specimens prepared from each root were resin coded for identification so that for any one experiment, the groups did not contain complementary specimens. Roots were presoaked in BHY medium for 2 days, and six roots per invasion experiment were selected at random and incubated fully submerged with pulpal surfaces upward in BHY medium containing streptococcal cells for 14 days exactly as described previously (34). At intervals of 3 days, the culture medium was removed (short of exposing the roots) and replaced with fresh medium. The viability of cells and purity of cultures were continually monitored (34). In some experiments, various proteins were added to BHY medium for the duration.

Light microscopy. Infected roots were fixed in $10 \%$ (wt/vol) formalin buffer at $\mathrm{pH} 7$, demineralized in $10 \%$ (wt/vol) formic acid containing $2 \%(\mathrm{wt} / \mathrm{vol})$ formalin, neutralized, washed, dehydrated, and blocked in wax (34). Ten transverse sections $(6 \mu \mathrm{m})$, each 10 sections apart, were cut from the coronal root dentine cervical area, stained (6), and viewed under low $(\times 100)$ magnification. The center of the root canal surface was identified, and from this position, the canal wall was divided into six equal lengths. The extent of bacterial invasion within each of these lengths was recorded at a magnification of $\times 400$ by determining the numbers of tubules containing bacteria. Where 1 to 20 tubules were infected, invasion was scored as 1 ; where 21 to 50 tubules were infected, invasion was scored as 2 ; when $>50$ tubules were infected, invasion was scored as 3 . To calculate the tubule invasion index (TI), scores were added and averaged for each section, each section score was added, and the mean was designated the TI for the root. A TI of $<0.5$ was classified as nil invasion, a TI of 0.5 to 1.0 was classified as mild invasion, a TI of 1.0 to 2.0 was classified as mild to moderate, a TI of $>2.0$ was classified as moderate to heavy, and a TI of $>2.5$ was classified as heavy. Data were analyzed by using Student's $t$ test. Sections that demonstrated external root resorption were disregarded, and further sections were cut until the defect was removed.

For the detection of bacterial antigens in infected roots, specimens were demineralized, fixed, and blocked in wax as described above, and sections $(4 \mu \mathrm{m})$ were cut and picked up onto gelatin-coated slides. Slides were heated at $60^{\circ} \mathrm{C}$ for $30 \mathrm{~min}$ and at $37^{\circ} \mathrm{C}$ for $16 \mathrm{~h}$, placed in xylene (twice for $10 \mathrm{~min}$ ), absolute ethanol (twice for $1 \mathrm{~min}$ ), and $2 \%$ (wt/vol) $\mathrm{H}_{2} \mathrm{O}_{2}$ in $95 \%$ (wt/vol) methanol (10 min), and finally rinsed with water. Nonspecific binding sites were blocked by incubating sections with $2 \%$ (wt/vol) bovine serum albumin (BSA) in Tris-buffered saline (TBS; $50 \mathrm{mM}$ Tris- $\mathrm{HCl}[\mathrm{pH} 7.5]$ containing $0.15 \mathrm{M} \mathrm{NaCl}$ ) at $20^{\circ} \mathrm{C}$ for $5 \mathrm{~min}$. Specimens were incubated with polyclonal antibodies to S. mutans SpaP (P1) protein (from K. W. Knox, Institute of Dental Research, University of Sydney, Sydney, Australia), which cross-react with $S$. gordonii antigen I/II polypeptides ( 9 , 23 ), diluted in the range of $1: 40$ to $1: 1,000$ with TBS-BSA. After $30 \mathrm{~min}$ of incubation, specimens were washed with TBS (twice for $15 \mathrm{~min}$ ) and incubated with peroxidase-conjugated swine anti-rabbit immunoglobulins (Dako Corporation, Carpinteria, Calif.), diluted 1:30 in TBS-BSA for $30 \mathrm{~min}$. Slides were washed, developed with 3,3'-diaminobenzidine, washed, and counterstained with hematoxylin. Negative controls (no primary antibodies) were included in every immunohistochemistry experiment.

To examine the effect of collagen on bacterial growth, cultures were incubated at $37^{\circ} \mathrm{C}$ for $18 \mathrm{~h}$ in $\mathrm{BHY}$ medium or in defined medium containing salts, amino acids, vitamins, and $0.8 \%$ (wt/vol) glucose (20), with or without acid-soluble collagen added, and cells were collected by centrifugation. Bacteria were suspended in TNMC buffer ( $1 \mathrm{mM}$ Tris- $\mathrm{HCl}[\mathrm{pH} 8.0]$ containing $0.15 \mathrm{M} \mathrm{NaCl}, 1$ $\mathrm{mM} \mathrm{MgCl} 2$, and $1 \mathrm{mM} \mathrm{CaCl}_{2}$ ), smears were prepared on glass slides, and cells were heat fixed, Gram stained, and visualized by light microscopy.

Electron microscopy. Demineralized and fixed root sections, prepared as described above, were dewaxed in xylene and rehydrated through absolute 90 and $70 \%$ (vol/vol) ethanol. Surfaces perpendicular to the pulpal surface were cut into a cone shape so that upon sectioning, dentinal tubules were cut transversely. Segments were rinsed in $0.1 \mathrm{M}$ sodium cacodylate adjusted to $\mathrm{pH} 7.3$ with $\mathrm{HCl}$, postfixed in $2 \%$ (wt/vol) $\mathrm{OsO}_{4}$ in cacodylate buffer at $4^{\circ} \mathrm{C}$ for $3 \mathrm{~h}$, dehydrated, and embedded in Spurrs resin. Sections ( $80 \mathrm{~nm}$ thick) were cut from the pulpal surface, stained with $5 \%(\mathrm{wt} / \mathrm{vol})$ uranyl acetate and $0.5 \%$ (wt/vol) lead citrate, and viewed with an Akashi EM-002A microscope.

Extraction of cell surface proteins, SDS-PAGE, and immunoblot analysis. Surface proteins were extracted from bacterial cells after incubation with mutanolysin (9). Protein concentrations were determined by Bio-Rad (Richmond, Calif.) protein assay with gamma globulins as standards. Polypeptides were subjected to sodium dodecyl sulfate-polyacrylamide gel electrophoresis (SDSPAGE) and stained with silver nitrate or transferred to nitrocellulose by electroblotting as described previously $(9,23)$. Blots were incubated with antibodies raised to purified SpaP (P1) protein from $S$. mutans at a 1:200 dilution or with the P1-specific monoclonal antibody 4-10A (5), diluted 1:7000, and antibody binding was revealed with peroxidase-conjugated secondary antibodies (23).

Preparation of collagen. Acid-soluble type I collagen (Sigma Chemical Co., St Louis, Mo.) was suspended in $0.01 \mathrm{M}$ acetic acid and filtered through a 0.45 $\mu \mathrm{m}$-pore-size filter. For the digestion of type I collagen (Sigma) with Clostridium histolyticum collagenase (Sigma), collagen was suspended $(2 \mathrm{mg} / \mathrm{ml})$ in $50 \mathrm{mM}$ Tris- $\mathrm{HCl}\left(\mathrm{pH} 7.0\right.$ ) containing $40 \mathrm{mM} \mathrm{CaCl}_{2}$ and incubated at $10^{\circ} \mathrm{C}$ for $18 \mathrm{~h}$ with collagenase at a substrate/enzyme ratio of $10: 1(45,47)$. The suspension was adjusted to $\mathrm{pH} 2.5$ with $1 \mathrm{~N} \mathrm{HCl}$ and dialyzed against $0.1 \%$ (wt/vol) acetic acid at $4^{\circ} \mathrm{C}$ for 4 days with three changes, and the contents of the dialysis bag were freeze-dried and suspended in $0.05 \%$ (wt/vol) acetic acid $(12 \mathrm{ml})$. The extent of collagen digestion was analyzed by SDS-PAGE, followed by staining of proteins with Coomassie blue R-250, and showed a pattern of bands in the range of 30 to $<100 \mathrm{kDa}(47)$. This preparation is referred to hereafter as collagen digest. To prepare an acid-released dentin matrix form of collagen, roots were denuded of cementum and ground in a tungsten carbide ball mill, and particles of $\leq 90 \mu \mathrm{m}$ were sieve selected and suspended at $5 \mathrm{mg} / \mathrm{ml}$ in $0.01 \mathrm{M}$ acetic acid for 60 days to solubilize them.

Adherence of streptococci to immobilized collagen. Portions $(50 \mu \mathrm{l})$ of collagen digest or acid-soluble collagen in coating buffer $\left(0.02 \mathrm{M} \mathrm{Na}_{2} \mathrm{CO}_{3}-\mathrm{NaHCO}_{3}\right.$ [pH 9.5]) or coating buffer alone (control) were added to wells of Maxi-Sorb microtiter plates (A/S Nunc, Kamstrup, Denmark) and incubated at $4^{\circ} \mathrm{C}$ for $16 \mathrm{~h}$. The remaining protein binding sites were blocked with $0.1 \%$ (wt/vol) BSA in TNMC buffer at $4^{\circ} \mathrm{C}$ for $16 \mathrm{~h}$. Wells were washed once with TNMC buffer, portions $(0.05 \mathrm{ml})$ of radioactively labeled streptococcal-cell suspension in TNMC buffer were added to each well, and plates were incubated with gentle 

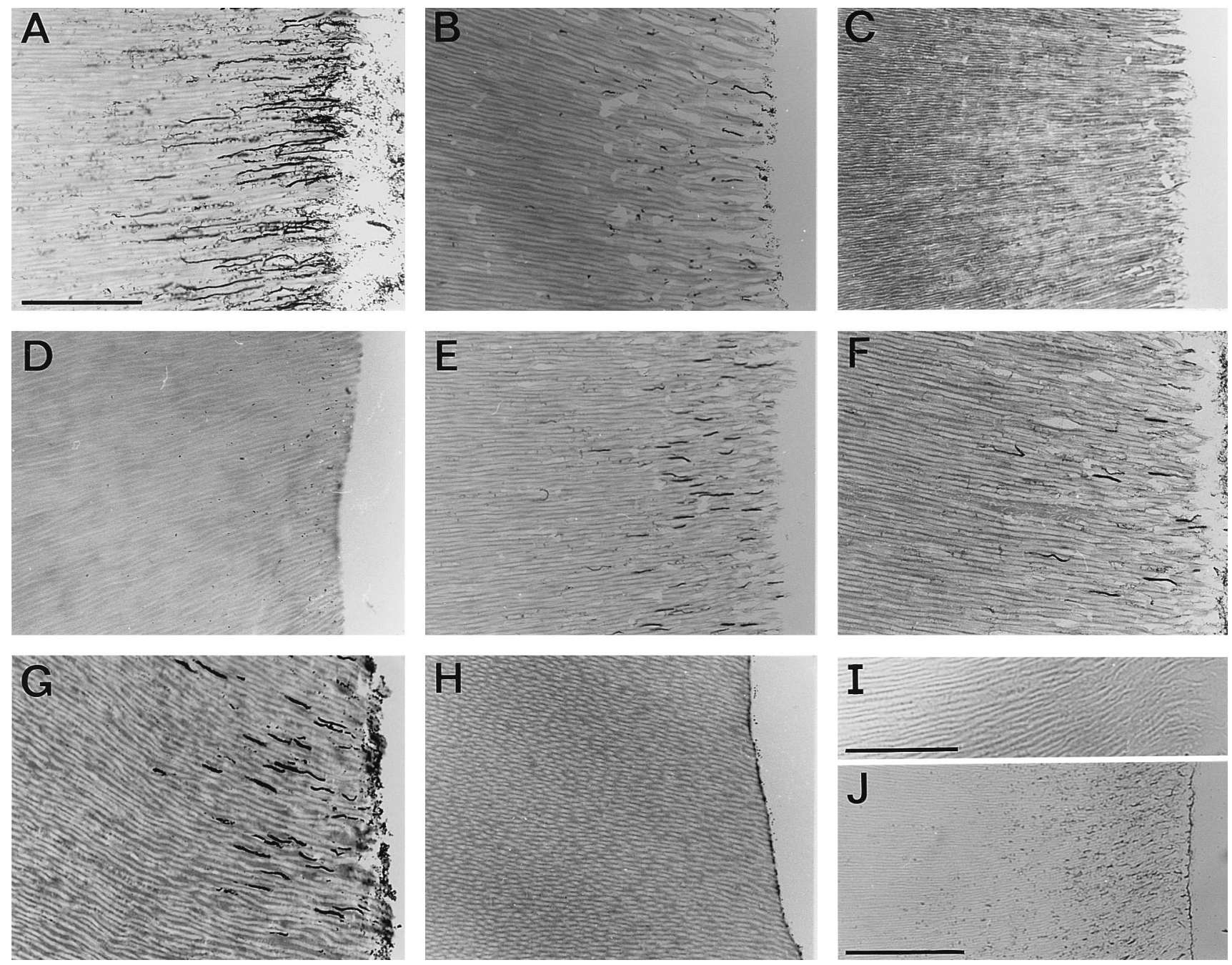

FIG. 1. Transverse sections of human roots showing the invasion of dentinal tubules from the pulpal side by various strains of streptococci. Bacterial cells were stained (A through H) (6) or detected immunohistochemically (I and J). (A) Wild-type S. gordonii DL1; (B) S. gordonii OB220 (sspA); (C) S. gordonii OB219 (sspA sspB); (D) S. gordonii DL1 in the presence of $0.2 \mathrm{mg}$ of collagen digest $/ \mathrm{ml}$; (E) S. gordonii OB573 (sspA SpaP ${ }^{+}$); (F) S. gordonii OB576 (sspA sspB SpaP ${ }^{+}$); (G) S. mutans NG8; (H) S. mutans 834 (spaP); I, S. gordonii DL1 reacted with an irrelevant rabbit serum (diluted 1:40); (J) S. gordonii DL1 reacted with SpaP (antigen I/II family) polypeptide antiserum (diluted 1:40). Note that in panels $\mathrm{G}$ and $\mathrm{H}$, bacteria adhered to the surface and formed a film; in panel $\mathrm{H}$, cells did not invade. Bars: 50 (A through $\mathrm{H}), 25(\mathrm{I})$, and $100(\mathrm{~J}) \mu \mathrm{m}$.

shaking $(200 \mathrm{rpm})$ at $37^{\circ} \mathrm{C}$ for $2 \mathrm{~h}$. The liquid contents of wells were discarded, wells were rinsed three times with TNMC buffer containing $0.05 \%$ (vol/vol) Tween 20, and adhered cells were stripped from wells and counted for radioactivity as previously described (23). Bacterial cell binding was proportional to the collagen added to wells in the range of 0.05 to $5 \mu \mathrm{g}$. The numbers of bacterial cells binding to $5 \mu \mathrm{g}$ of collagen digest were proportional to the numbers of cells added up to an input of $8 \times 10^{7}$ cells, at which point binding sites became saturated. To test the inhibition of bacterial adhesion by free collagen, portions of collagen digest or acid-soluble collagen solutions containing up to $20 \mu \mathrm{g}$ of protein were added directly to adhesion assays.

\section{RESULTS}

Antigen I/II family proteins determine the abilities of $S$. gordonii and $S$. mutans cells to invade dentinal tubules. Previous studies have established the experimental conditions under which cells of $S$. gordonii DL1 (Challis) reproducibly invade dentinal tubules (34). Randomly selected human tooth roots were incubated with $S$. gordonii cultures at $37^{\circ} \mathrm{C}$ for 14 days, washed, fixed, sectioned, and visualized by light microscopy. After this period of incubation, more than $50 \%$ of root tubules were invaded by streptococci, and these were present both as individual pairs or small groups of cells and as groups of longer chains that penetrated to $200 \mu \mathrm{m}$ or more (Fig. 1A). Not all tubules were invaded by wild-type cells, and the penetration depth was variable (Fig. 1A) for the reasons outlined below (see Discussion). We developed a method to quantify the degree of invasion based on the number of tubules infected per unit area (see Materials and Methods). This provided a TI of $2.76 \pm 0.31$ for the wild-type strain (Table 2), against which the TIs of other strains were subsequently compared.

In view of the evidence that antigen I/II family polypeptides are multifunctional cell surface adhesins in streptococci (21), we tested the abilities of isogenic ssp mutants of $S$. gordonii to invade dentinal tubules. Mutant strain OB220 ( $\operatorname{sp} A$ ), expressing only the SspB polypeptide (Fig. 2), showed a considerably reduced level of invasion (Table 2), and cells were present within tubules mainly singly or in short chains (Fig. 1B). Antigen I/II polypeptide production by strain OB219 cells was abolished (Fig. 2), and no tubule invasion by these cells was observed (Fig. 1C). To determine whether these effects were 
TABLE 2. Streptococcal-cell invasion of dentinal tubules and adhesion to collagen

\begin{tabular}{llll}
\hline $\begin{array}{c}\text { Bacterial } \\
\text { strain }\end{array}$ & \multicolumn{1}{c}{$\begin{array}{c}\text { Antigen I/II } \\
\text { phenotype }\end{array}$} & $\begin{array}{c}\text { Mean TI } \pm \mathrm{SD} \\
(n=6)^{a}\end{array}$ & $\begin{array}{c}\text { No. of cells ad- } \\
\text { hered to collagen } \\
\left(10^{6}\right) \pm \mathrm{SD} \\
(n=4)^{b}\end{array}$ \\
\hline $\begin{array}{l}\text { S. gordonii } \\
\text { DL1 }\end{array}$ & $\mathrm{SspA}^{+} \mathrm{SspB}^{+}$ & $2.76 \pm 0.31$ & $4.68 \pm 0.57$ \\
OB220 & $\mathrm{SspA}^{-} \mathrm{SspB}^{+}$ & $1.13 \pm 0.27(0.000)$ & $2.73 \pm 0.21(0.001)$ \\
OB219 & $\mathrm{SspA}^{-} \mathrm{SspB}^{-}$ & $0.36 \pm 0.29(0.000)$ & $1.59 \pm 0.17(0.000)$ \\
OB573 & $\mathrm{SppA}^{-} \mathrm{SspB}^{+} \mathrm{SpaP}^{+}$ & $2.38 \pm 0.44(0.073)$ & $5.46 \pm 0.58(0.093)$ \\
OB576 & $\mathrm{SspA}^{-} \mathrm{SspB}^{-} \mathrm{SpaP}^{+}$ & $2.12 \pm 0.37(0.002)$ & $3.72 \pm 0.38(0.030)$ \\
& & & \\
S. mutans & & $2.54 \pm 0.24$ & $1.86 \pm 0.15$ \\
NG8 & $\mathrm{SpaP}^{+}$ & $0.52 \pm 0.28$ & $0.39 \pm 0.02$ \\
834 & $\mathrm{SpaP}^{-}$ & & \\
\hline
\end{tabular}

${ }^{a}$ Calculated as described in Materials and Methods. TI of $<0.5$, nil invasion; TI of $\geq 2.5$, heavy invasion. Parenthetical data are $P$ values for TI data compared with the result for strain DL1.

${ }^{b}$ Five micrograms of collagen digest was immobilized on microtiter plate wells, and the numbers of radioactively labeled streptococcal cells adhered (input, $3 \times 10^{7}$ cells) were measured as described in Materials and Methods. Parenthetical data are $P$ values for adhesion data compared with the result for strain DL1.

due directly to the loss of antigen I/II proteins, we introduced plasmid pAM401-EB5, carrying the $\operatorname{sspB}$ gene (8), into $S$. gordonii OB219. However, whereas the $s s p B$ gene product was expressed from this plasmid in Enterococcus faecalis (8), no expression of SspB polypeptide was detected in S. gordonii OB219, even though the plasmid was stably maintained. We introduced plasmid $\mathrm{pSMI} / \mathrm{II}-3$, carrying the $S$. mutans spaP gene (19), into $S$. gordonii ssp mutants to generate strains OB573 and OB576 (Table 1). Cells of strain OB573 expressed both $\mathrm{SspB}$ and SpaP proteins, as detected with antigen I/II polyclonal antibodies (Fig. 2A), whereas SpaP protein was detected with a SpaP-specific monoclonal antibody (Fig. 2B). Cells of strain OB576 expressed only SpaP, as detected with monoclonal antibody (Fig. 2B), apparently at a level higher than that in strain OB573 (Fig. 2B). Both OB573 and OB576 were restored in their abilities to invade dentinal tubules (Fig. $1 \mathrm{E}$ and $\mathrm{F}$ ), with OB573 showing a TI not significantly different $(P=0.073)$ from that of the DL1 wild-type strain (Table 2$)$ and OB576 being restored to $85 \%$ of the wild-type TI (Table 2). These results implied a direct, non-species-specific role for antigen I/II polypeptide in tubule invasion by streptococci. In further support of this, $S$. mutans NG8 cells, expressing SpaP (Fig. 2), showed proficient invasion of dentinal tubules (Fig. $1 G)$, whereas cells of 834, an isogenic spaP mutant strain, did not (Fig. 1H; Table 2). S. gordonii OB277 cells, in which the production of cell surface polypeptides CshA and CshB is abrogated (37), exhibited a TI similar to that of the wild-type strain (data not shown). Lastly, by reacting demineralized sections of roots invaded by $S$. gordonii DL1 cells with SpaP polyclonal antibodies followed by immunohistochemical staining, we determined that Ssp polypeptides were expressed by the bacteria growing within dentinal tubules (Fig. 1J). There was no reaction of an irrelevant rabbit serum with streptococcal cells within adjacent sections (Fig. 1I).

Inhibition of dentinal tubule invasion by free collagen. Since collagen type I is a major component of dentin, we tested the ability of acid-soluble collagen or collagen digest (see Materials and Methods), incorporated into culture medium, to inhibit the invasion of tubules by $S$. gordonii DL1 cells. Both soluble collagen preparations were found to inhibit invasion in a dosedependent manner. Invasion was reduced by approximately
$50 \%$ in the presence of $0.1 \mathrm{mg}$ of collagen $/ \mathrm{ml}$ and was abrogated (TI, $<0.47 \pm 0.32$ ) with $0.2 \mathrm{mg}$ of collagen $/ \mathrm{ml}$ (Fig. 1D). The addition of fibrinogen or transferrin (each at $0.5 \mathrm{mg} / \mathrm{ml}$ ) to culture medium had no effect on tubule invasion by wild-type cells (data not shown).

Antigen I/II polypeptides are associated with streptococcal adhesion to collagen. Since antigen I/II family polypeptides are adhesins, it seemed likely that streptococcal-cell invasion of tubules was related to the binding properties of these polypeptides. One possibility was that Ssp polypeptides in S. gordonii normally bound to intratubular collagen (7) and that by blocking this binding, free collagen inhibited invasion. We therefore compared the adhesion of wild-type and mutant cells to collagen type I preparations immobilized on microtiter plate wells. Preliminary experiments established that wells coated with 5 $\mu \mathrm{g}$ of collagen type I digest supported maximal adhesion of wild-type $S$. gordonii cells and that adhesion was inhibitable by free collagen (70\% inhibition of binding by $20 \mu \mathrm{g}$ of collagen [data not shown]). The ability of $S$. gordonii OB220 (ssp $A$ ) cells to bind to collagen was reduced by $42 \%$ (Table 2), and cells of the double mutant OB219 ( $\operatorname{ss} A \operatorname{ssp} B$ ) showed only approximately $30 \%$ adhesion, compared with that of the wild type (Table 2). Cells of strain OB573, expressing S. mutans SpaP protein, adhered somewhat better to collagen than did cells of strain DL1 (Table 2), and the adhesion of OB576 cells was restored to $80 \%$ of that of the wild type (Table 2). S. mutans NG8 cells adhered to collagen less well than did $S$. gordonii DL1 cells, and the adhesion of 834 (spaP) mutant cells to collagen was only $20 \%$ of that of NG8 (Table 2). These data strongly suggested that the antigen I/II family polypeptides in both $S$. gordonii and $S$. mutans were involved in the binding of cells to collagen. Furthermore, there appeared to be a direct correlation between the ability of cells to bind collagen and the ability to penetrate and invade dentinal tubules.

Streptococci attach to the walls of dentinal tubules. Transmission electron microscopy was utilized to discern more clearly the mode of streptococcal growth within dentinal tubules. Although the demineralization process, which was necessary for fixation and staining, led to shrinkage and some deformation of bacterial cells, electron micrographs showed clearly that streptococcal cells adhered to the walls of tubules and that fibrillar material was concentrated at the site of association between the bacterial cell surface and tubule (Fig. 3A). In some sections, it was possible to discern striations

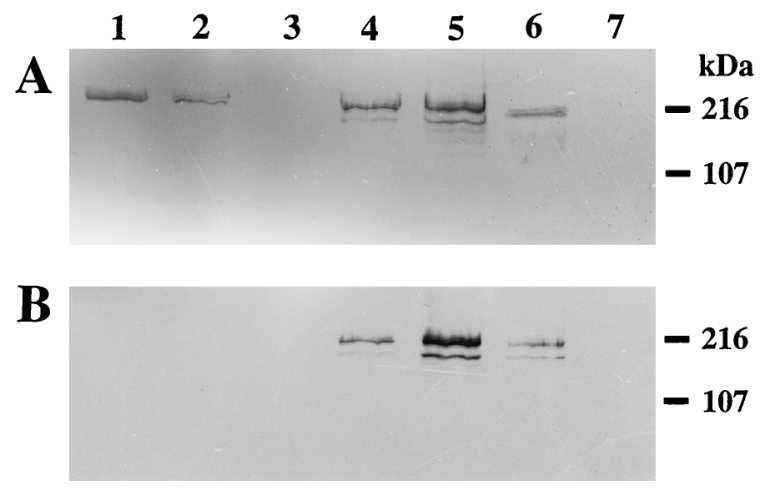

FIG. 2. Immunoblot detection of antigen I/II family polypeptides in streptococcal-cell surface protein extracts with polyclonal antibodies raised to $S$. mutans SpaP (A) or SpaP-specific monoclonal antibody 4-10A (B). Lanes: 1, S. gordonii DL1; 2, S. gordonii OB220 (sspA); 3, S. gordonii OB219 (sspA sspB); 4, S. gordonii OB573 (ssp A SpaP ${ }^{+}$); 5, S. gordonii OB576 (sspA sspB SpaP ${ }^{+}$); 6, S. mutans NG8; 7, S. mutans 834 (spaP). The positions of molecular mass markers are indicated. 

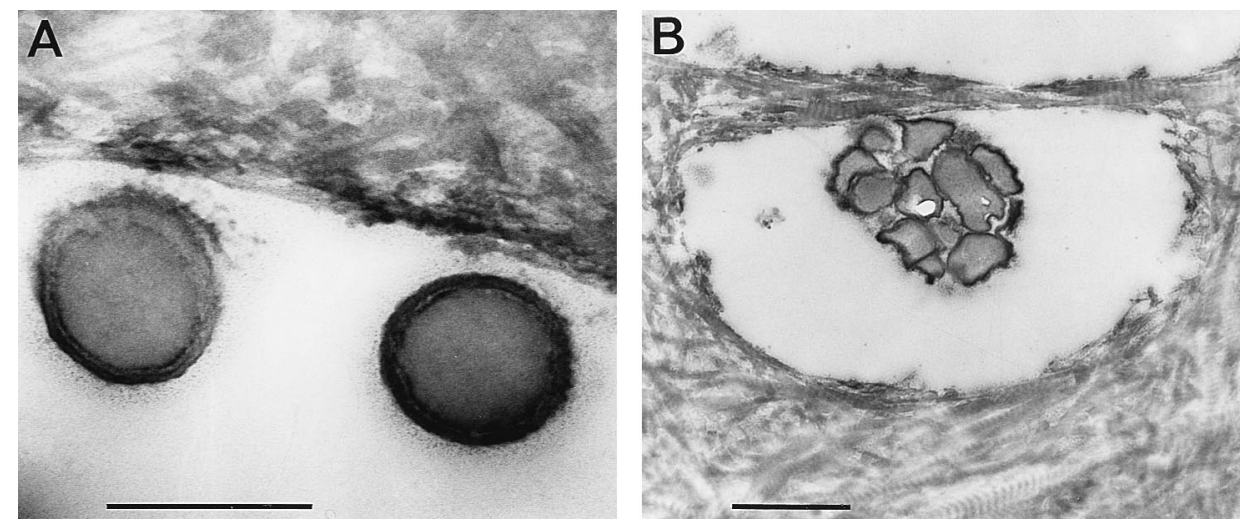

FIG. 3. Transmission electron micrographs of sections cut parallel to the pulpal surface of human tooth roots infected with $S$. gordonii DL1. (A) Individual bacterial cells associated with the lumen wall of a dentinal tubule. Magnification, $\times 56,000$. Bar, $0.5 \mu \mathrm{m}$. (B) Group of streptococcal cells in intimate contact with the tubule wall, with striations characteristic of collagen bundles visible. Magnification, $\times 14,000$. Bar, $1.0 \mu \mathrm{m}$.

within the dentin matrix that are characteristic of collagen bundles (Fig. 3B). Groups of bacterial cells were enveloped by diffusely staining material and held in contact with the tubule wall (Fig. 3B).

S. gordonii exhibits an antigen I/II polypeptide-mediated growth response to collagen. $S$. gordonii DL1 formed short chains of cells in BHY medium (Fig. 4A) but formed long and intertwined chains of cells in BHY medium containing $0.2 \mathrm{mg}$ of acid-soluble collagen/ml (Fig. 4D). Cells also exhibited this morphological mode of growth in BHY medium containing collagen digest or acid-released dentin matrix (not shown). Mutant OB219 ( $\operatorname{sp} A$ sspB) cells showed growth morphology similar to that of DL1 cells (Fig. 4B), but they did not form long chains in the presence of collagen (Fig. 4E). Significant long chaining of strain OB576 cells, expressing $S$. mutans SpaP protein, occurred in the presence of collagen (compare Fig. 4C and F), although this was not as extensive as that of wild-type cells. The morphotypic responses of DL1 and OB576 cells to collagen were identical when a defined salts medium containing glucose, instead of BHY medium, was utilized.

SspA polypeptide expression in $S$. gordonii DL1 is induced by collagen. To determine whether antigen I/II polypeptide expression in $S$. gordonii was affected by the presence of collagen, bacteria were grown in $\mathrm{BHY}$ medium with or without collagen. Proteins were extracted from the surfaces of bacterial cells, subjected to SDS-PAGE, and transferred to nitrocellulose, and blots were reacted with antigen I/II polyclonal antibodies. The expression of antigen I/II polypeptides by $S$. gordonii DL1 was enhanced by collagen and exhibited a dose response (Fig. 5A). The polyclonal antibodies reacted with both SspA and SspB polypeptides, which formed a doublet with an apparent molecular mass $210 \mathrm{kDa}$, and with a degra-
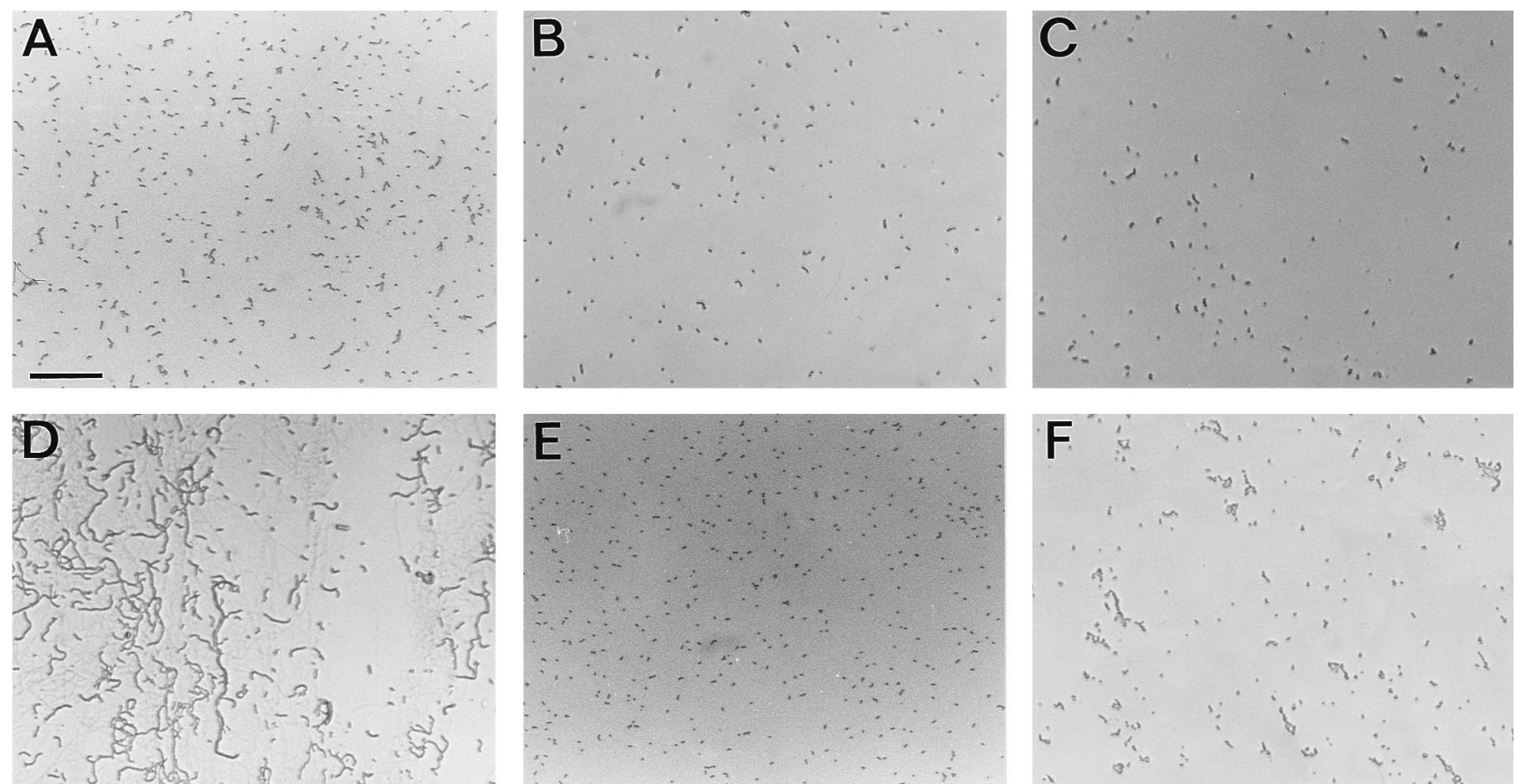

FIG. 4. Effects of acid-soluble collagen on the growth morphology of S. gordonii cells in liquid culture. (A through C) BHY medium; (D through F) BHY medium containing $0.2 \mathrm{mg}$ of collagen digest $/ \mathrm{ml}$. (A and D) S. gordonii DL1; (B and E) S. gordonii OB219 (sspA sspB); (C and F) S. gordonii OB576 (sspA sspB SpaP ${ }^{+}$). 


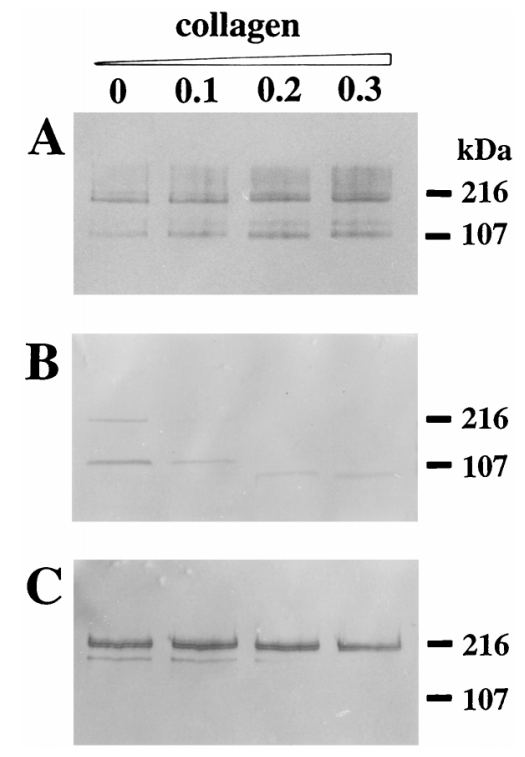

FIG. 5. Effects of adding increasing amounts of acid-soluble collagen (in milligrams per milliliter) on the production of antigen I/II polypeptides by wildtype and mutant $S$. gordonii strains growing in BHY medium. Cell surface polypeptides were extracted as described in Materials and Methods, separated by SDS-PAGE, transferred to a nitrocellulose membrane, and reacted with polyclonal antibodies (diluted 1:200) to $S$. mutans SpaP (P1) polypeptide. (A) $S$. gordonii DL1; (B) S. gordonii OB220 (sspA); (C) S. gordonii OB576 (sspA sspB $\left.\mathrm{SpaP}^{+}\right)$. Each lane was loaded with an equivalent amount of protein $(12 \pm 1.5$ $\mu \mathrm{g})$. The positions of molecular mass marker proteins are indicated.

dation product with an approximate molecular mass of 110 $\mathrm{kDa}$ (Fig. 5A). As expected, there was no reaction of OB219 $(\operatorname{ssp} A \operatorname{ssp} B)$ cell surface protein extracts with antibodies (not shown). However, the production of $\mathrm{SspB}$ polypeptide by OB220 $(\operatorname{ssp} A)$ cells appeared to be somewhat reduced in the presence of collagen (Fig. 5B), with further degradation of the $110-\mathrm{kDa}$ band. The production of plasmid-encoded SpaP polypeptide by OB576 cells was relatively unaffected by the presence of collagen (Fig. 5C).

\section{DISCUSSION}

Sanguis group streptococci have often been utilized in previous studies to investigate the factors that influence the penetration of dentinal tubules by oral bacteria (42). Under the experimental conditions generally employed in those studies, bacterial culture medium penetrates into the tubules of tooth roots and provides sufficient nutrients for bacterial cells that have penetrated the tubules to grow and remain viable for extended periods. Streptococci characteristically form chains of cells and grow along the lengths of tubules, appearing to colonize the tubule walls (41). The average depth of bacterial penetration seems to depend in the main upon the manner in which the tooth roots are prepared (33). For example, S. sanguis cells penetrated $>400 \mu \mathrm{m}$ into bovine incisor tissue with the cementum removed (41), whereas in our experiments utilizing human root tissue with the cementum intact (34), $S$. gordonii cells rarely penetrated deeper than $200 \mu \mathrm{m}$. Not all dentinal tubules become infected by streptococci. Some tubules may be blocked, perhaps as a result of hypermineralization, thus preventing the penetration of bacteria and/or restricting the diffusion of solutes. Some tubules may be constricted, which also severely retards solute diffusion. The rate of solute diffusion, which influences bacterial growth (32), is proportional to the surface area of the tubule, the diameter of which can vary from $2.5 \mu \mathrm{m}$ at the pulpal wall to $0.9 \mu \mathrm{m}$ at the peripheral dentin (12). This results in a decreasing diffusion rate along the length of the tubule and limits bacterial growth peripherally (32). Furthermore, as we have shown here, it is possible that recognition of collagen by bacteria is critical for invasion. Collagen has previously been reported to be found in an unmineralized form in $65 \%$ of tubules (7), so this may also be a factor in determining the proportion of tubules invaded by bacterial cells.

The evidence presented here clearly demonstrates a role for antigen I/II family polypeptides in determining the abilities of at least two species of oral streptococci to invade dentinal tubules. S. gordonii produces two antigen I/II family proteins, $\mathrm{SspA}$ and $\mathrm{SspB}$, that are the products of tandemly arranged and independently expressed chromosomal genes $(9,10)$. Both SspA and SspB polypeptides have previously been implicated in the adhesion of $S$. gordonii to salivary agglutinin glycoprotein and to oral bacteria such as $A$. naeslundii (9). The binding properties of these polypeptides have now been extended to include collagen. The presence of these polypeptides, which are expressed on the surfaces of bacteria growing within tubules (Fig. 1J), specifically correlates with the ability of $S$. gordonii to invade dentinal tubules. Isogenic mutants that fail to produce cell surface protein adhesins CshA and CshB (37) are unaffected in their ability to invade dentinal tubules. In $S$. mutans, the SpaP polypeptide appears to play a role similar to that of SspA and SspB in S. gordonii in that it is involved in collagen recognition and clearly determines the ability of $S$. mutans cells to invade dentinal tubules. Other streptococcal strains, such as Streptococcus sobrinus 6715 and Streptococcus oralis $\mathrm{H} 1$, that produce antigen I/II family polypeptides are also proficient in the invasion of dentinal tubules (data not shown). These observations, taken collectively with the results demonstrating that expression of $S$. mutans $\mathrm{SpaP}_{\text {by Ssp }}^{-}$mutants of $S$. gordonii restored their ability to invade tubules, suggest that this is a conserved function among antigen I/II proteins rather than a species-specific property.

Several binding properties of antigen I/II polypeptides have been ascribed to specific regions within the primary sequence of the antigen I/II molecule. For example, the binding of salivary glycoproteins is associated both with alanine-rich sequences within the $\mathrm{NH}_{2}$-terminal region and with sequences $\mathrm{COOH}$ terminal to the proline-rich central region of the molecule (reviewed in reference 21). Recently, it has been shown that $\mathrm{NH}_{2}$-terminal region fragments of the antigen I/II polypeptide $\mathrm{Sr}$ from $S$. mutans are able to bind collagen and other human tissue proteins (43). It is possible therefore that $\mathrm{NH}_{2}$-terminal region sequences, some of which are well-conserved across species (21), are involved in collagen recognition. Although our results suggest that antigen I/II polypeptides mediate the adhesion of cells to collagen, we believe that the activity of these polypeptides in determining the ability to invade dentinal tubules extends further than merely an adhesive function. This is supported by several observations. Firstly, although $S$. gordonii cells abrogated in SspA and SspB production still exhibited a level of collagen binding, albeit reduced, this was insufficient to permit tubule invasion. Secondly, other oral bacterial species, such as lactobacilli (35) and A. naeslundii, adhere to collagen $(17,31)$ but do not have the ability to invade dentinal tubules (41). Thirdly, streptococci that express antigen I/II polypeptides on their surfaces exhibit a marked morphological growth response to the presence of collagen in the growth medium. This mode of growth is remarkably similar to the intratubular growth of cells penetrating deeply into dentinal tubules (Fig. 1A). Thus, it is suggested that antigen I/II polypeptides, as well as being multiligand adhesins (21), 
mediate a collagen-specific growth response which accounts for the ability of cells to penetrate tubules.

It has previously been suggested, based on similarities in sequence and overall domain structure, that antigen I/II polypeptides form part of a larger family of cell wall-associated polypeptides found also in E. faecalis and Lactococcus lactis (14). The Asc1 and Asc10 polypeptides (1,305 and 1,296 aa residues, respectively) produced by $E$. faecalis are cell surface proteins that promote the aggregation of donor and recipient cells, enabling the transfer of a sex pheromone plasmid. In addition, the Asc1 polypeptide mediates the binding of enterococci to cultured renal tubular cells (26). In L. lactis, the CluA polypeptide (1,243 aa residues) functions similarly to the Asc proteins in that it is involved in donor cell aggregation and sex factor transfer (14). The best homologies among these proteins reside $\mathrm{NH}_{2}$ terminal to the alanine-rich sequences and $\mathrm{COOH}$ terminal to the proline-rich sequence within the region of antigen I/II that is involved in binding to salivary glycoproteins and $\mathrm{Ca}^{2+}$ ions $(21,24)$. Therefore, all these proteins may be components of environmentally responsive systems that facilitate cell-cell contact, adhesion, and community development.

Collagen adhesins in Streptococcus pyogenes (49) and in some strains of Staphylococcus aureus (13) have previously been described. There is no significant sequence similarity between the Staphylococcus aureus Cna collagen adhesin and antigen I/II polypeptides. There is also no published evidence that the expression of these collagen adhesins is regulated by collagen. However, production of the PAAP protein in $S$. sanguis, which contains a collagen-like domain that induces the aggregation of human platelets $(11,18)$, and production of a $145-\mathrm{kDa}$ surface protein in S. gordonii (44) are regulated by both collagen and laminin. The observation that antigen I/II expression in $S$. gordonii is also induced by collagen or collagen peptides raises the possibility that these proteins are components of a response network in streptococci to environmental sensing of collagen or other specific eukaryotic factors. The exact relationship, if any, between the $145-\mathrm{kDa}$ collagen-induced protein in $S$. gordonii and antigen I/II family polypeptides is under investigation. Possibly the binding of collagen to antigen I/II proteins triggers transcriptional responses, including activation (or derepression) of antigen I/II protein gene expression. Alternatively, collagen or collagen peptides act via a sensor/regulator system to transcriptionally regulate expression of antigen I/II polypeptides. The available evidence tends to suggest that antigen I/II polypeptides themselves have a sensing function, since heterologous expression of SpaP in $S$. gordonii OB219 restored collagen adhesion, collagen-responsive growth morphology, and the ability to invade dentinal tubules.

An interesting observation is that collagen did not induce, rather it inhibited somewhat, the production of SspB polypeptide by OB220 cells. While we cannot rule out the possibility that in OB220 the insertion of ermAM within $\operatorname{ssp} A$ interferes with transcriptional control of downstream $\operatorname{ssp} B(10)$, the data strongly suggest that it is the production of SspA polypeptide in the wild-type strain that is upregulated in response to collagen. This indicates further that the $\operatorname{ssp} A$ and $\operatorname{ssp} B$ gene promoters may be differentially regulated in response to collagen; this is being investigated by utilizing promoter-reporter gene fusions. Further indications as to the relative roles of $\mathrm{SspA}$ and SspB polypeptides in collagen recognition and binding by $S$. gordonii may be achieved by analyzing an isogenic $\operatorname{ssp} B$ mutant, which we have not yet succeeded in generating. Lastly, the production of SpaP polypeptide by OB576 cells was not enhanced by collagen. This supports the view that increased antigen I/II protein production in the presence of collagen is related to a transcriptional effect on the $\operatorname{ssp} A$ chromosomal promoter rather than a posttranslational effect of collagen on, for example, antigen I/II protein stability.

In summary, $S$. gordonii and $S$. mutans cells exhibit binding to collagen and a growth response to collagen, mediated by antigen I/II proteins. The ability of bacterial cells to invade tubules may depend upon both these antigen I/II activities, and the growth response in particular may be crucial to the invasion process and account for the ability of cells to penetrate tubules deeply. The observation that free collagen prevented tubule invasion by streptococci raises the possibility that soluble collagen preparations or collagen analogs are useful in preventing endodontic streptococcal infections. Furthermore, for more than 25 years, there has been considerable interest in developing anticaries strategies, such as a vaccine based on streptococcal antigen I/II family polypeptides (21). The results presented here indicate that targeting the activities of these polypeptides may be not only relevant for controlling coronal caries but also significant for controlling root caries and pulpal infections.

\section{ACKNOWLEDGMENTS}

We thank S. F. Lee for generously providing plasmid pSMI/II-3 and monoclonal antibody to SpaP polypeptide, A. S. Bleiweis for kindly supplying $S$. mutans NG8 and 834, and K. W. Knox for providing polyclonal antibodies to SpaP. We are most grateful to R. A. Baker, S. M. Johnstone, and A. Samways for technical assistance and to R. $\mathrm{McNab}$ for comments on the manuscript.

\section{REFERENCES}

1. Akpata, E. S., and M. Blechman. 1982. Bacterial invasion of pulpal dentin wall in vitro. J. Dent. Res. 61:435-438.

2. Baddour, L. M. 1994. Virulence factors among gram-positive bacteria in experimental endocarditis. Infect. Immun. 62:2143-2148.

3. Beighton, D., and E. Lynch. 1995. Comparison of selected microflora of plaque and underlying carious dentine associated with primary root caries lesions. Caries Res. 29:154-158.

4. Bowden, G. H. W., J. Ekstrand, B. McNaughton, and S. J. Challacombe. 1990. The association of selected bacteria with lesions of root surface caries. Oral Microbiol. Immunol. 5:346-351.

5. Brady, L. J., D. A. Piacentini, P. J. Crowley, and A. S. Bleiweis. 1991. Identification of monoclonal antibody-binding domains within antigen P1 of Streptococcus mutans and cross-reactivity with related surface antigens of oral streptococci. Infect. Immun. 59:4425-4435.

6. Brown, J. H., and L. Brenn. 1931. A method for the differential staining of gram-positive and gram-negative bacteria in tissue sections. Bull. Johns Hopkins Hosp. 48:69-73.

7. Dai, X.-F., A. R. Ten Cate, and H. Limeback. 1991. The extent and distribution of intratubular collagen fibrils in human dentine. Arch. Oral Biol. 36:775-778.

8. Demuth, D. R., P. Berthold, P. S. Leboy, E. E. Golub, C. A. Davis, and D. Malamud. 1989. Saliva-mediated aggregation of Enterococcus faecalis transformed with a Streptococcus sanguis gene encoding the SSP-5 surface antigen. Infect. Immun. 57:1470-1475.

9. Demuth, D. R., Y. Duan, W. Brooks, A. R. Holmes, R. McNab, and H. F. Jenkinson. 1996. Tandem genes encode cell-surface polypeptides SspA and $\mathrm{SspB}$ which mediate adhesion of the oral bacterium Streptococcus gordonii to human and bacterial receptors. Mol. Microbiol. 20:403-413.

10. Demuth, D. R., Y. Duan, H. F. Jenkinson, R. McNab, S. Gil, and R. J. Lamont. 1997. Interruption of the Streptococcus gordonii M5 sspA/sspB intergenic region by an insertion sequence related to IS1167 of Streptococcus pneumoniae. Microbiology 143:2047-2055.

11. Erickson, P. R., and M. C. Herzberg. 1995. Altered expression of the platelet aggregation-associated protein from Streptococcus sanguis after growth in the presence of collagen. Infect. Immun. 63:1084-1088.

12. Garberoglio, R., and M. Brännström. 1976. Scanning electron microscopic investigation of human dentinal tubules. Arch. Oral Biol. 21:355-362.

13. Gillaspy, A. F., J. M. Patti, and M. S. Smeltzer. 1997. Transcriptional regulation of the Staphylococcus aureus collagen adhesin gene, cna. Infect. Immun. 65:1536-1540.

14. Godon, J. J., C. J. Pillidge, K. Jury, C. A. Shearman, and M. J. Gasson. 1995. Molecular analysis of the Lactococcus lactis sex factor. Dev. Biol. Stand. 85:423-430.

15. Haapasalo, M., and D. Ørstavik. 1987. In vitro infection and disinfection of dentinal tubules. J. Dent. Res. 66:1375-1379. 
16. Haisman, R. J., and H. F. Jenkinson. 1991. Mutants of Streptococcus gordonii Challis over-producing glucosyltransferase. J. Gen. Microbiol. 137:483-489.

17. Hawkins, B. W., R. D. Cannon, and H. F. Jenkinson. 1993. Interactions of Actinomyces naeslundii T14V and ATCC 12104 with saliva, collagen and fibrinogen. Arch. Oral Biol. 38:533-535.

18. Herzberg, M. C. 1996. Platelet-streptococcal interactions in endocarditis. Crit. Rev. Oral Biol. Med. 7:222-236.

19. Homonylo-McGavin, M. K., and S. F. Lee. 1996. Role of the C terminus in antigen P1 surface localization in Streptococcus mutans and two related cocci. J. Bacteriol. 178:801-807.

20. Jenkinson, H. F. 1986. Cell-surface proteins of Streptococcus sanguis associated with cell surface hydrophobicity and coaggregation properties. J. Gen. Microbiol. 132:1575-1589.

21. Jenkinson, H. F., and D. R. Demuth. 1997. Structure, function and immunogenicity of streptococcal antigen I/II polypeptides. Mol. Microbiol. 23: 183-190.

22. Jenkinson, H. F., and R. J. Lamont. 1997. Streptococcal adhesion and colonization. Crit. Rev. Oral Biol. Med. 8:175-200.

23. Jenkinson, H. F., S. D. Terry, R. McNab, and G. W. Tannock. 1993. Inactivation of the gene encoding surface protein SspA in Streptococcus gordonii DL1 affects cell interactions with human salivary agglutinin and oral actinomyces. Infect. Immun. 61:3199-3208.

24. Kelly, C. G., S. Todryk, H. L. Kendal, G. H. Munro, and T. Lehner. 1995 T-cell, adhesion, and B-cell epitopes of the cell surface Streptococcus mutans protein antigen I/II. Infect. Immun. 63:3649-3658.

25. Koga, T., N. Okahashi, I. Takahashi, T. Kanamoto, H. Asakawa, and M. Iwaki. 1990. Surface hydrophobicity, adherence, and aggregation of cell surface protein antigen mutants of Streptococcus mutans serotype $c$. Infect. Immun. 58:289-296.

26. Kreft, B., R. Marre, U. Schramm, and R. Wirth. 1992. Aggregation sub stance of Enterococcus faecalis mediates adhesion to cultured renal tubular cells. Infect. Immun. 60:25-30.

27. Lawry, J., and L. M. Switalski. 1996. Cloning and expression of collagen adhesin of Streptococcus mutans. J. Dent. Res. 75:96. (Abstract.)

28. Lee, S. F., A. Progulske-Fox, G. W. Erdos, D. A. Piacentini, G. Y. Ayakawa, P. J. Crowley, and A. S. Bleiweis. 1989. Construction and characterization of isogenic mutants of Streptococcus mutans deficient in major surface protein antigen P1 (I/II). Infect. Immun. 57:3306-3313.

29. Linde, A. 1989. Dentin matrix proteins: composition and possible functions in calcification. Anat. Rec. 224:154-166.

30. Liu, T., and R. J. Gibbons. 1990. Binding of streptococci of the "mutans" group to type 1 collagen associated with apatitic surfaces. Oral Microbiol. Immunol. 5:131-136.

31. Liu, T., R. J. Gibbons, D. I. Hay, and Z. Skobe. 1991. Binding of Actinomyces viscosus to collagen: association with the type 1 fimbrial adhesin. Oral Microbiol. Immunol. 6:1-5.

32. Love, R. M. 1996. Regional variation in root dentinal tubule infection by Streptococcus gordonii. J. Endod. 22:290-293.
33. Love, R. M. 1996. Bacterial penetration of the root canal of intact incisor teeth after a simulated traumatic injury. Endod. Dent. Traumatol. 12:289293.

34. Love, R. M., N. P. Chandler, and H. F. Jenkinson. 1996. Penetration of smeared or nonsmeared dentine by Streptococcus gordonii. Int. Endod. J. 29:2-12.

35. McGrady, J. A., W. G. Butcher, D. Beighton, and L. M. Switalski. 1995. Specific and charge interactions mediate collagen recognition by oral lactobacilli. J. Dent. Res. 74:649-657.

36. McNab, R., A. R. Holmes, and H. F. Jenkinson. 1995. Cell-surface polypeptides as determinants of hydrophobicity in Streptococcus gordonii and Streptococcus sanguis. Colloids Surf. 5:135-142.

37. McNab, R., A. R. Holmes, J. M. Clarke, G. W. Tannock, and H. F. Jenkinson. 1996. Cell surface polypeptide CshA mediates binding of Streptococcus gordonii to other oral bacteria and to immobilized fibronectin. Infect. Immun. 64:4204-4210.

38. Moisset, A., N. Schatz, Y. Lepoivre, S. Amadio, D. Wachsmann, M. Scholler, and J.-P. Klein. 1994. Conservation of salivary glycoprotein-interacting and human immunoglobulin G-cross-reactive domains of antigen I/II in oral streptococci. Infect. Immun. 62:184-193.

39. Pakula, R., and W. Walczak. 1963. On the nature of competence of transformable streptococci. J. Gen. Microbiol. 31:125-133.

40. Pashley, D. H. 1990. Clinical considerations of microleakage. J. Endod. 16:70-77.

41. Perez, F., T. Rochd, J.-P. Lodter, P. Calas, and G. Michel. 1993. In vitro study of the penetration of three bacterial strains into root dentine. Oral Surg. Oral Med. Oral Pathol. 76:97-103.

42. Peters, L. B., P. R. Wesselink, and W. R. Moorer. 1995. The fate and the role of bacteria left in root dentinal tubules. Int. Endod. J. 28:95-99.

43. Sciotti, M.-A., J.-P. Klein, and J. A. Ogier. 1996. Ligand-binding specificity of different domains of antigen I/II. J. Dent. Res. 75:313. (Abstract.)

44. Sommer, P., C. Gleyzal, S. Guerret, J. Etienne, and J.-A. Grimaud. 1992 Induction of a putative laminin-binding protein of Streptococcus gordonii in human infective endocarditis. Infect. Immun. 60:360-365.

45. Stark, M., and K. Kühn. 1968. The properties of molecular fragments obtained on treating calfskin collagen with collagenase from Clostridium histolyticum. Eur. J. Biochem. 6:534-541.

46. Sundqvist, G. 1994. Taxonomy, ecology, and pathogenicity of the root canal flora. Oral Surg. Oral Med. Oral Pathol. 78:522-530.

47. Switalski, L. M., W. G. Butcher, P. C. Caufield, and M. S. Lantz. 1993. Collagen mediates adhesion of Streptococcus mutans to human dentin. Infect. Immun. 61:4119-4125.

48. Tanzer, J. M. 1992. Microbiology of dental caries, p. 377-424. In J. Slots and M. A. Taubman (ed.), Contemporary oral microbiology and immunology. Mosby-Year Book Inc., St. Louis, Mo.

49. Visai, L., S. Bozzini, G. Raucci, A. Toniolo, and P. Speziale. 1995. Isolation and characterization of a novel collagen-binding protein from Streptococcus pyogenes strain 6414. J. Biol. Chem. 270:347-353.

Editor: V. A. Fischetti 